doi: 10.15503.jecs2021.2.469.481

Journal of Education Culture and Society No. 2_2021

\title{
TRANSCRIPTION OF FOREIGN PERSONAL NAMES IN THE WRITTEN WORKS OF LEARNERS OF LATVIAN AS A FOREIGN LANGUAGE
}

\author{
ANTRA KLIAVINSKA \\ Rezekne Academy of Technologies \\ Atbrīvošanas aleja 115, Rēzekne, LV-4601 Latvia \\ E-mail address: antra.klavinska@rta.lv \\ ORCID: http://orcid.org/0000-0001-8991-1457
}

\begin{abstract}
Aim. The aim of this study is to analyse how personal names are transcribed in the written works of Latvian as foreign language learners, as well as the most typical mistakes when transcribing personal names in other languages, the attitude of students towards the Latvianisation of their personal names, and the experience of Latvian language teachers in teaching the principles of transcribing personal names.

Methods. The study uses the corpus analysis method, as well as a survey of students and survey of teachers who teach Latvian as a foreign language. The article includes error analysis of the personal name transcription established in the corpus and the analysis of the survey results.

Results and conclusion. It was found out that students mostly know how to transcribe their names in Latvian; less frequently do they know how their surname should be transcribed. Their attitude towards Latvianisation of personal names is various: positive, negative or neutral. Latvian as a foreign language teachers emphasise the principle of transcription of foreign personal names and the need to provide its justification in the study process. It was concluded that further Latvian language acquisition process needs to be focused more on the problems with transcription of foreign personal names.

Originality. This study highlights the aspect that is little researched in the applied linguistics - the issued linked to transcription of foreign personal names in the process of learning the Latvian language. The novelty is related to the use of a new resource (error-tagged learner corpus) data.
\end{abstract}

Key words: Latvian as foreign language, learner corpus, transcription of personal names, error analysis

\section{INTRODUCTION}

Tistorically, the Latvian language has developed a requirement to transcribe foreign personal names, using the sounds and letters of the Latvian language and in accordance with their pronunciation in the language of their origin and the grammatical system of the Latvian language. In the Latvian language, 
the grammatical meanings - gender, number, case - of personal names (with the exception of indeclinable personal names) are expressed with declinable endings. Regulations of the Cabinet of Ministers No. 114, Regulations regarding the written form and use in the Latvian language of personal names, and also identification thereof (2004), stipulates that foreign personal names must be transcribed in Latvian pursuant to their pronunciation in the original language and to the grammatical system of the Latvian language. However, linguists believe that the issue of transcription of foreign proper names should be addressed in the aspect of language styles. For identification of a personal name, it is desirable to indicate the original spelling in brackets after the Latvian transcription in official documents (business style), scientific research (scientific language style) and press publications (publicist style) (Strautina \& Šulce, 2009).

Latvian universities teach the Latvian language to students from different countries of the world, and traditions for writing personal names in their native languages often differ quite significantly from the conventions observed in Latvian. This is why pronunciation and transcription of foreign personal names in the Latvian language often poses difficulty not only for the students but also teachers. Name and surname are an integral part of an individual's identity and private life, which is why Latvian language learners are often surprised how foreign personal names can sometimes change in the Latvian language. For example, the name of the American actor, film director, producer and screenwriter George Timothy Clooney is transcribed in Latvian as follows: Džordžs Timotijs Klūnijs.

The description of Latvian language proficiency levels states that a language learner at level A must be able to spell and write their own name and the names of their family members, but transcription rules for specific foreign personal names in Latvian need to be acquired at level B (Šalme \& Auziña, 2016).

Research questions:

- How foreign personal names (mainly first names) are transcribed in the written works by Latvian as a foreign language learners (level A1, A2); what problems students have with the transcription of the sounds of a foreign language using the letters of the Latvian language, as well as with the use of endings in personal names?

- What is self-assessment of knowledge about the conditions of transcription of foreign personal names of foreign students who study in Latvia and learn Latvian; what is the attitude of the students towards Latvianisation of their personal names?

- What is the experience of Latvian as a foreign language teachers in teaching the principles of transcribing personal names in other languages?

\section{METHODOLOGY}

This is a corpus-based research (Tognini-Bonelli, 2001), and the data have been obtained from the Latvian Language Learner Corpus (hereinafter LaVA). "A learner corpus is a corpus produced by learners of a particular lan- 
guage. Learner corpora can be useful in allowing teachers to identify common errors at various stages of development (...)" (Baker, 2018, p. 175).

The LaVA corpus contains almost 1000 student essays (more than 180 thousand words in total). Data for LaVA corpus:

[is] gathered from international students studying in higher education institutions in Latvia and learning Latvian as foreign language in formal courses at these institutions. Language teachers from multiple higher education institutions have agreed to support the corpus creation process by asking their students to write essays on various topics. (...) The students are asked not to include any personal information in the essay regardless of the topic. (Darǵis, Auziņa, Levāne-Petrova, \& Kaija, 2020, p. 393)

Thus, the personal names used in the texts are not the real names of the students or their relatives. For example, when writing the essay "My Family," the students were asked to write about an imaginary family. The students have shown creativity and mentioned world-famous celebrities, such as Britney Spears (Britnija Spīrsa), Madonna, Messi (Mesi), Ronaldinho (Ronaldinju), Albert Einstein (Alberts Einšteins), as family members. Typical Latvian personal names, such as Ilze, Ruta, Māris, Toms, are also used in the texts. However, generally the students have chosen the system of personal names typical for their native language.

The LaVA corpus can help find out what causes the most difficulty for Latvian language learners and which words and word forms are used most frequently. The corpus allows searching using metadata, i.e., information about gender, age, native language, and foreign language skills of language learners.

During the creation of text corpora and error tagging, a taxonomy of the errors found in the written works of Latvian language learners with the classification of error types and subtypes was created: 1) spelling errors (upper/ lower case letter, diacritics, words spelled separately/together, missing letters, redundant letters, other spelling errors); 2) punctuation errors (missing punctuation, redundant punctuation, incorrect punctuation); 3) grammatical errors (incorrect word form, involving inadequate inflection, gender, number, definiteness, tense, person, derivation, morphophonemic consonant alternation); 4) syntactic errors (word order, redundant word, missing word); 5) lexical errors (meaning, compliance, readability, collocation); 6) unclear text (Darǵis, Auziña, \& Levāne-Petrova, 2018).

One of the basic concepts in corpus linguistics is the theory on collocations - in the general sense collocations are combinations of words which usually occur in the vicinity of each other (Sinclair, 1991). Collocations for the following lexemes were searched for in the LaVA corpus: sauc/mani sauc 'my name is', vinu sauc 'his/her name is', vinus sauc 'their names are' - 317 were tokens found (including cases where several personal names were mentioned in the concordance column, including names of pets, as well as 11 instances where a blank space is left, not mentioning any personal name); 
vārds 'name' - 78 tokens (including 10 instances where the students had left a blank space in their essays, not mentioning any name); uzvārds 'surname' - 28 tokens (including 5 instances with a blank space without a surname). In total, 470 personal names (422 names and 48 surnames) were found in the LaVa corpus.

The main corpus research tools are concordances (i.e., lists of words and word forms) and statistical analysis tools. A concordance is a list of words or collocations found in a corpus, which allows finding repeated patterns (McEnery \& Hardie, 2012). Since LaVA is an error-tagged corpus, each token is presented in two concordance lines - in the text produced by the student and in the tagged and reconstructed text where the errors have been corrected (see Figure 1). Thus, the corpus shows which personal name the student has used in the essay and how it would be rendered correctly in the Latvian language.

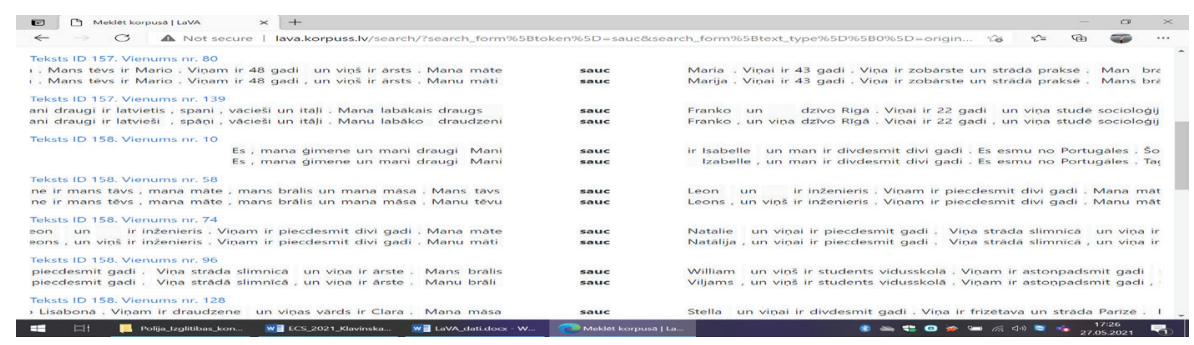

Fig. 1. Concordance columns in the learner corpus.

Source: Learner Corpus of Latvian (LaVA).

Next, a qualitative analysis of the errors made when transcribing foreign personal names was performed.

The aims of the studies regarding error analysis can be summarised as follows: Error analysis identifies the strategies that language learners use. It looks for the answer of the question 'why do learners make errors?' It determines the common difficulties in learning and helps teachers to develop materials for remedial teaching. (Erdoğan, 2005, p. 269)

In this study, by analysing the errors, the author tried to answer the following questions: whether and how foreign language sounds were transcribed using Latvian letters and whether appropriate endings of the personal names were used (morphosyntactic analysis).

Additionally, to find out how the learners of Latvian as a foreign language evaluate their knowledge and what they think about Latvianisation of personal names, an online survey was conducted in May 2021 using Google Forms. 38 respondents participated in the survey. To explore the experience of the teachers of Latvian as a foreign language when introducing the transcribing of foreign personal names, an online survey for Latvian language teachers was conducted in May 2021, and seven teachers have responded. 


\section{THE MOST COMMON ERRORS IN TRANSCRIBING PERSONAL NAMES}

Among 470 personal names (including 422 names and 48 surnames) obtained in the LaVA corpus, there are 243 names and 22 surnames which were erroneously transcribed. Most errors are spelling errors, but there were also established grammatical errors (i.e., the lack of relevant masculine or feminine endings or use of incorrect ending) as well as capitalisation errors.

If foreign students used personal names typical of the Latvian language in their texts (for example, Māris, Roberts, Anna, Inese), which are often mentioned in teaching aids, they rarely made errors. Only in some cases there are errors in writing a vowel - short vowels are used instead of long vowels (there is no macron above a vowel or vice versa - a macron is used in a wrong place). It is a typical error made by non-Latvians in writing down any Latvian text. For example, in Latvian, the typical masculine name Jānis is spelled incorrectly: Janis or Janis, the feminine name Liene is spelled with a long vowel in the ending Lien $\overline{\boldsymbol{e}}$ (locative case for the ending in singular). In such cases, it is difficult to determine whether it is a spelling error or a grammatical error.

When using foreign personal names in the text, there are two types of errors typical of the Latvian language learners: 1) most often personal names are written in the original spelling; 2 ) personal names are transcribed inaccurately.

In the personal names which are used in the Latvian text in the original spelling (or Latinised according to the norms of the English language) sometimes there are written letters that are not in the Latvian alphabet $(w, q, x, y, \bar{o})$, for example, Max (correct - Makss), Ivy (Ivija). When placing a personal name in the Latvian text in the original spelling, its pronunciation might cause problems (e.g., incoherence with pronunciation). For example, in Latvian, the word Jason would be pronounced as ['jason], the correct transcription in Latvian, adding a masculine ending typical of Latvian, would be Džeisons ['dzessons].

Another issue is related to the use of endings in personal names, for example, using the French personal surname Alexandre in a Latvian text could lead to a misconception about a person's gender, because in Latvian the ending -e is typical of feminine nouns (correct transcription - Aleksandrs). Many personal names written in the original language lack the relevant endings, for example, in masculine gender (-s) Martin (Martins), Paul (Pauls), in feminine gender $(-a,-e)$ Elisabeth (Elizabete). The lack of endings is mostly observed in masculine personal names, perhaps because in students' mother tongues, the endings of feminine personal names coincide with the endings of feminine personal names in Latvian.

A small number of capitalisation errors were found: in Latvian, as in many other languages, proper names are written capitalising the first letter. In some cases, in the texts of foreign students, the personal name is written with the initial letter in lower case, for example, cindy (Sindija), chantal (Šantala), lakas (Lakass), ina (Ina), philip (Filips). This type of errors could also be considered as errors due to negligence. A more detailed discussion on capitalisation errors in LaVA corpus texts could be found in another study (Kļavinska, 2021). 
Inaccurately transcribed personal names more often contain spelling errors, and less often - grammatical errors. Also in this group, spelling errors are mainly related to incorrect reproduction of short or long consonants, such as Klara (correct $K l \bar{a} r a)$, Anastāzija (Anastasija), as well as incorrect reproduction of consonants, such as Wladimirs (Vladimirs), Aljona (Alona). Grammatical errors occur in writing the ending or suffix together with the ending of a personal name, for example, Luciferis (correct Lucifers), Andrejas (Andrejs), Maria (Marija).

\section{SURVEY OF FOREIGN STUDENTS}

In May 2021, there was conducted a survey in order to find out the self-assessment of foreign students studying in Latvia and Latvian language learners, knowledge about the conditions for rendering foreign personal names in Latvian, as well as to determine students' attitudes towards the Latvianisation of personal names. The survey was conducted electronically, and the participation was voluntary and anonymous.

38 foreign students studying at different Latvian higher education institutions, who are learning Latvian for the first year (28 respondents) and third year (10 students) participated in the study. In the beginning of the survey, students specified their mother tongue(s): German, Swedish, Finnish, Russian, Norwegian, Danish, Italian, Arabic, Persian and Spanish. They answered six closed questions by choosing one of the offered answer options.

In the students' self-assessment, when asked about the principles of how to render foreign language personal names, it was acknowledged that $21(55 \%)$ of all respondents do not know these conditions, and 16 respondents (45\%) do know them (see Figure 2). The first and third year students gave both affirmative and negative answers.

\section{Do you know what are the principles of transcription of foreign personal names in Latvian?}

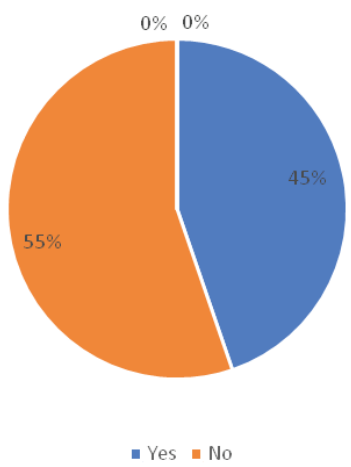

Fig. 2. Students' self-assessment of knowledge of the conditions on transcription of foreign personal names in Latvian.

Source: own research. 
Journal of Education Culture and Society No. 2_2021

The results of the survey show that most students $25(66 \%)$ know how their names are rendered into Latvian, while only 12 (32\%) of the students know how to reproduce their surnames (see Figure 3).

\section{Do you know how your name and surname is transcribed in Latvian?}

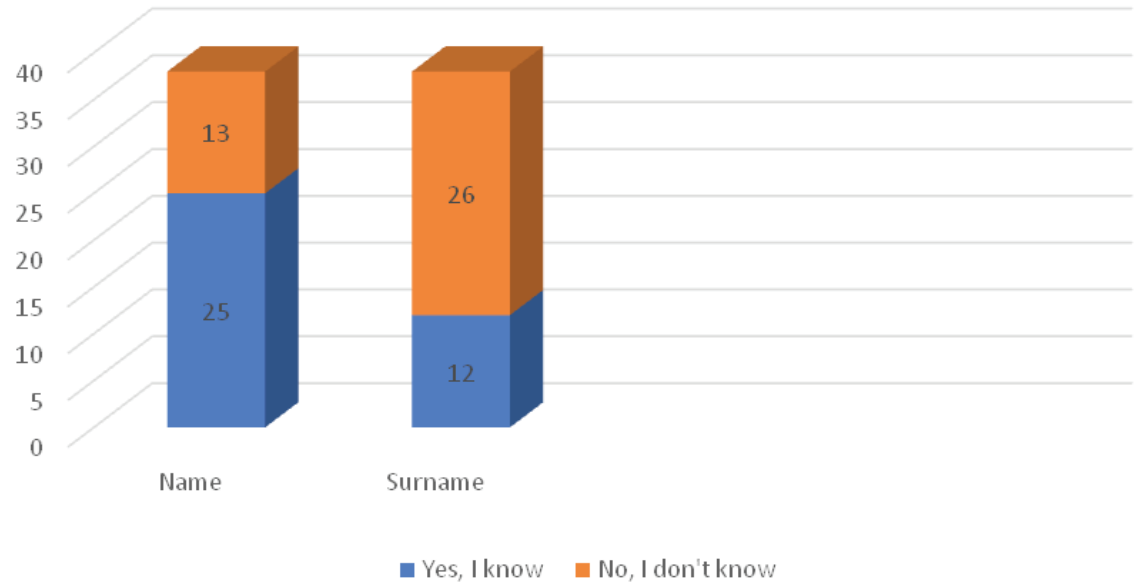

Fig. 3. Students' self-assessment of knowledge of rendering their names and surnames in Latvian.

Source: own research.

Only 4 (11\%) respondents) admit that they do not like the way their personal name is rendered in Latvian. 34\% express neutral attitude, 26\% like the way their personal name is represented in Latvian, 29\% have no opinion about this question (see Figure 4). 
Do you like how your personal name (s) is / are transcribed in Latvian?

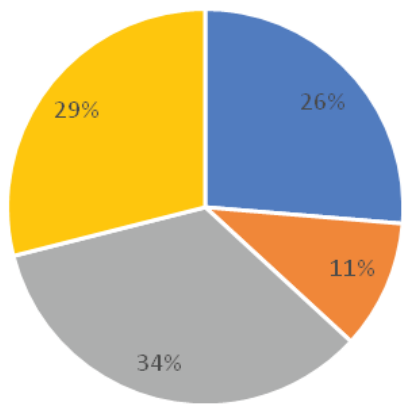

- Yes, I like = No, I don't like $=$ Neutral $=$ I don't know

Fig. 4. Students' attitude towards the rendering their personal names in Latvian. Source: own research.

Four respondents (10\%) indicate that their Latvianised personal name does not differ from the entry in the personal documents - these are the students who specified German and Norwegian as their mother tongue, $17(45 \%)$ admit that the transcribed personal name slightly differs, but $5(13 \%)$ point out that it is very different from what is written in the documents - among these there are the students whose mother tongue is German, Danish and Finnish (see Figure 5).

\section{Is the transcription of your name in Latvian different from your personal documents?}

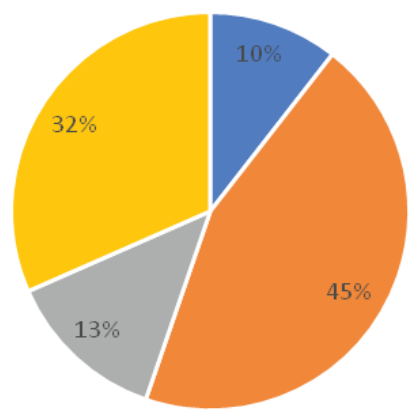

$$
\text { - No = Yes, a little } \quad \text { Yes, verymuch }=\text { Idon't know }
$$

Fig. 5. Comparison of the transcription of a personal name in Latvian with an entry in personal documents.

Source: own research. 
The majority of respondents (53\%) express neutral attitude towards the requirement to transcribe foreign language personal names according to their pronunciation in the original language and include them in the grammatical system of the Latvian language, 25\% have positive attitude, 13\% - negative, and $8 \%$ have no opinion (see Figure 6).

\section{What is your attitude towards the requirement to transcribe foreign personal names in accordance with their pronunciation in the language of their origin and to adapt them to the grammatical system of the Latvian language?}

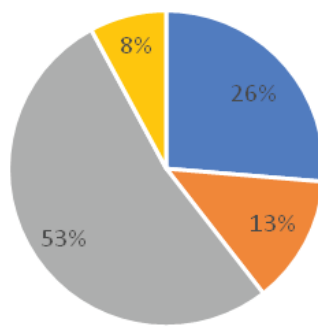

- Positive = Negative " Neutral $\mid$ Idon't know

Fig. 6. Students' attitude towards the requirement to transcribe foreign language personal names according to their pronunciation in the original language and to include them in the grammatical system of the Latvian language.

Source: own research.

\section{EXPERIENCE OF LATVIAN AS A FOREIGN LANGUAGE TEACHERS}

In order to investigate the experience of Latvian as a foreign language teachers introducing the transcription of foreign personal names in Latvian, an electronic interview of Latvian language teachers was organised in May 2021. The teachers who teach Latvian as a foreign language at both Latvian and foreign universities were asked three open questions:

- In the lessons, do you address the issue of transcription of foreign personal names? If yes, in which semester/in the context of which topics? What teaching aids and Internet resources do you use to acquire this topic?

- In the lessons, do you explain how the personal names (first name, surname) of specific students are transcribed in Latvian? If yes, what is their attitude towards the fact that the personal name transcribed in Latvian differs from the original spelling?

- Do students use their Latvianised personal names in spoken and written works during the lessons of Latvian? 
Seven lecturers provided answers: two of them teach Latvian abroad and five - in Latvia. In the article, the respondents are encrypted, indicating a country where the lecturer teaches Latvian (DE - Germany, LT - Lithuania, LV Latvia) and a number.

Sharing their experience of teaching how to transcribe personal names, the lecturers admit that they do not devote separate lessons to this topic, as it is integrated into acquisition of other topics. The greatest attention is paid to the transcription of students' names, and the issue of surname transcription is raised less frequently. This topic is mostly discussed in the first Latvian language lessons (in the first semester of learning):

I usually explain in the beginning of the first semester that we Latvianise everything. At first, I say what their names would be like with Latvian endings. We also talk about this when it comes to the subject 'Countries and languages'. Then we try to Latvianise cities as well. But it is not taught specially (LV 5).

One of the reasons why there are no separate classes devoted to the transcription of personal names is the limited number of lessons and the opportunity to raise this issue in the process of acquiring other topics:

When there were more lessons of Latvian in the study programme, sometimes I added the topic of personal names to the topic of ordinals; namely, we learned to tell date and say when their name days and birthdays are. Since I am extremely interested in origin of personal names and in calendars, I usually create a name day calendar for a group, showing both how to transcribe a student's name in Latvian and offering alternatives from the Latvian calendar, e.g., Hadar - Ada; Michel - Mikselis, etc. (LV1).

Speaking of teaching aids and Internet resources, Latvian language teachers mention not only the name day calendar as a specific 'auxiliary material' in transcription of personal names, but also other resources: regulation on transcription of surnames, an application for transcription of personal names in different languages (LT1).

The resource Rendering of personal names in Latvian is rather good, but not all languages and all names are there. In my opinion, there is a lack of a general brief introduction for foreigners about the basic principles of transcription and grounds why transcription is necessary (LV1).

Moreover, any textbook of Latvian language or electronic teaching aid includes texts with both Latvian and non-Latvian personal names; consequently, these resources are also useful for talking about personal names and their inclusion in the grammatical system of the Latvian language:

(...) usually in the beginning of the first semester, when we learn genders of a noun, personal names also come up in Latvian in both genders. Then I also explain that you can tell to which gender a certain name belongs by the suffix of a personal name. In this lesson, I also tell them that their names and surnames would be Latvianised. I do not use any specific materials for this purpose. It matches any teaching aid that is used in acquisition of Latvian as a foreign language when teaching genders (LV3). 
Teachers have noticed that students' attitude towards transcription of their personal names according to the conditions of the Latvian language differs:

There are some who like to attach macrons and endings and consistently use them, too. There are others who do not do it even in writing (..). Many perceive transcription of personal names as something amusing and a game. Although they know what it is supposed to be like, they most often try to write personal names in the original form (DE1).

Teachers admit that students should not be forced to Latvianise their personal names: 'From the position of a lecturer, I always respect the students' opinion on this sensitive issue' (LV1). Explaining the reasons for Latvianisation of personal names facilitates formation of a positive attitude:

I explain that we transcribe names so that Latvians know how to address them and so that they can grammatically understand who is who (..). There were cases where people were surprised and to some extent protested that it is another name, but when I explained how it is meant, they understood and accepted it. Probably, positive attitude is formed also by the fact that some students have already experienced at least one 'transcription' - those whose mother tongue (in which the personal name is) uses a non-Latin alphabet (Chinese, Arabic, Sri Lankan...), have already gone through a phase of 'Latinisation'. Therefore, changing spelling of a name is not new to them. In addition, they have already experienced a situation when people often cannot pronounce their words in their original spelling, so clarity of pronunciation is an understandable argument for them (LV2).

\section{CONCLUSIONS AND RECOMMENDATIONS}

Latvian language teacher in Japan Daiki Horiguči admits that "personal names can be considered one of the elements of the language culture because their usage reflects the nation's culture, traditions and way of thinking" (Horiguči, 2010, p. 34). In his classes, at the initial stage of learning, students are asked to choose themselves a Latvian personal name from a Latvian calendar which will be used to address them during the rest of the learning process. The initial purpose was to understand that Latvian personal names have declensions just like other nouns, as well as the opportunity to practice using different forms of declension (Horiguči, 2010). Thus, students acquire a deeper insight into the system of Latvian personal names.

The issue of transcribing foreign personal names in the Latvian language has been the subject of discussion for linguists as well as general society for many years. On the one hand, not changing foreign personal names allows preserving the person's identity, which is especially important in business, scientific, and journalistic writing. On the other hand, Latvianisation of personal names facilitates their pronunciation and inclusion into the grammatical system of the Latvian language. Correct transcription of personal names is problematic not only for foreign students but also for Latvians because first we 
need to establish how the personal name is pronounced, which letters should be used use to transcribe the sounds which do not exist in the Latvian language, and which word ending should be chosen. Of course, there are many auxiliary tools: rules for transcribing personal names of various origin have been published since 1960, and the application Rendering of personal names in Latvian has also been created (Latvian Language Agency, 2017).

In the Latvian language acquisition process, the issues related to transcribing foreign personal names need to be addressed with gradually increasing attention: transcription of the sounds of the original language, grammaticalisation possibilities of foreign personal names; explaining the motivation for the transformation of personal names, and forming a positive attitude to the Latvian language traditions.

\section{ACKNOWLEDGEMENTS}

The work reported in this paper is part of the Latvian State Research Programme "Latvian Language" (No. VPP-IZM-2018/2-0002), subproject "Acquisition of Latvian Language." I would like to express my gratitude to the foreign students studying in Latvia and Latvian language teachers involved in this study.

\section{REFERENCES}

[1] Baker, P. (2018). Corpus methods in linguistics. In: L. Litosseliti (Ed.) Research methods in linguistics (pp. 167-191). London, New York, Oxford, New Deli, Sydney: Bloomsbury Academic.

[2] Darǵis, R., Auziņa, I., \& Levāne-Petrova, K. (2018). The use of text alignment in semi-automatic error analysis: Use case in the development of the corpus of the Latvian language learners. In: N. Calzolari, K. Choukri, C. Cieri, T. Declerck, S. Goggi, K. Hasida, H. Isahara, B. Maegaard, J. Mariani, H. Mazo, A. Moreno, J. Odijk, S. Piperidis \& T. Tokunaga (Eds.), Proceedings of the 11th International Conference on Language Resources and Evaluation (LREC 2018) (pp. 4111-4115). European Language Resources Association (ELRA).

[3] Darǵis, R., Auziņa I., Levāne-Petrova, K., \& Kaija, I. (2020). Quality focused approach to a learner corpus development. In: N. Calzolari, F. Béchet, P. Blache, K. Choukri, C. Cieri, T. Declerck, S. Goggi, H. Isahara, B. Maegaard, J. Mariani, H. Mazo, A. Moreno, J. Odijk \& S. Piperidis (Eds.), Proceedings of the 12th International Conference on Language Resources and Evaluation (pp. 392-396). Marsielle: European Language Resources Association.

[4] Erdoğan, V. (2005). Contribution of error analysis to foreign language teaching. Mersin University Journal of the Faculty of Education, 1(2), 261- 270.

[5] Horiguči, D. (2010). Kopības sajūta klasē - piemērs no latviešu valodas apguvējiem japāniem [Sense of togetherness in class - the case of Japanese Latvian language learners]. In: D. Laiveniece (Ed.), Valodu apguve: problēmas un perspektīva. Zinātnisko rakstu kräjums [Language acquisition: Problems and prospects. A collection of scientific articles] (pp. 28-37). Liepāja: LiePA.

[6] Klavinska, A. (2021). Capitalisation errors in written works of learners of Latvian as a foreign language. In: V. Lubkina, G. Strods \& O. Vindaca (Eds.), Society. Integration. Education. Proceedings of the International Scientific Conference, 19 (pp. 282-291). Rezekne: Rezekne Academy of Technologies.

[7] Latvian Language Agency. (2017). Rendering of personal names in Latvian. Retrieved May 21, 2021, from https://www.personvarduatveide.lv/. 
[8] Latvian Language Learner Corpus (2018-2021). Latviešu valodas apguvēju korpuss. Latvijas Universitātes Matemātikas un informātikas institūts [The Latvian language learner corpus. University of Latvia, Institute of Mathematics and Computer Science]. Retrieved May 21, 2021, from http:/ /lava.korpuss.lv/.

[9] McEnery, T., \& Hardie, A. (2012). Corpus linguistics: Method, theory and practice. Cambridge: Cambridge University Press.

[10] Regulations regarding the written form and use in the Latvian language of personal names, and also identification thereof (2004). Cabinet of Ministers Regulation No. 114, adopted in Riga on December 2, 2004, Latvijas Vēstnesis. Retrieved May 21, 2021, from https://likumi.lv/doc. php?id=85209.

[11] Sinclair, J. (1991). Corpus, concordance, collocation. Oxford, UK: Oxford University Press.

[12] Strautina, V., \& Šulce, Dz. (2009). Latviešu valodas pareizruna un pareizrakstiba [Latvian language pronunciation and spelling]. Rìga: RaKa.

[13] Salme, A., \& Auziņa, I. (2016). Latviešu valodas prasmes lìmeņi: pamatlìmenis A1, A2, vidējais limenis B1, B2 [Latvian language proficiency levels: Basic user A1, A2, independent user B1, B2]. Rīga: Latviešu valodas aǵentūra.

[14] Tognini-Bonelli, E. (2001). Corpus linguistics at work. Amsterdam: John Benjamins Publishing. 